University for Business and Technology in Kosovo

UBT Knowledge Center

UBT International Conference

2012 UBT International Conference

Nov 2nd, 9:00 AM - Nov 3rd, 5:00 PM

\title{
Contemporary Lightening Methods in Architecture
}

Vlora Aliu

University for Business and Technology, vlora.aliu@ubt-uni.net

Follow this and additional works at: https://knowledgecenter.ubt-uni.net/conference

Part of the Architecture Commons

\section{Recommended Citation}

Aliu, Vlora, "Contemporary Lightening Methods in Architecture" (2012). UBT International Conference. 24. https://knowledgecenter.ubt-uni.net/conference/2012/all-events/24

This Event is brought to you for free and open access by the Publication and Journals at UBT Knowledge Center. It has been accepted for inclusion in UBT International Conference by an authorized administrator of UBT Knowledge Center. For more information, please contact knowledge.center@ubt-uni.net. 


\title{
CONTEMPORARY LIGHTNING METHOD IN ARCHITECTURE
}

\author{
can. MSc Vlora Aliu ${ }^{1}$ \\ ${ }^{1}$ University for Business and Technology (UBT) \\ vlora.aliu@ubt-uni.net
}

\begin{abstract}
Human beings are forced to conceive their life as a practical and conceptual development and in harmony with global technology and trends. As the main necessity in our world right now is the sustainable architecture and alternative and green energy incorporation in every possible way that will impact in energy saving and environmental protection.
\end{abstract}

In this context, today it is more than necessary that ecological friendly energy is a part of architecture philosophy as a crucial part in global energy efficiency.

Use of material, the human need for consume and increasing exploitation of natural resources, such as underground and ground resources, makes people to search for other alternatives in order to fulfill their needs?

Analytic concept:

Glow in dark is a material which can be used to save energy since it emits light after sun exposure. It is has zero energy consumption and is environmentally friendly. Main ingredients of this material are: water, cement, lime material, pigments and color.

According to researchers in energy efficiency, this material is suggested to be used in facilities such as: different kind of theaters, underpasses, tunnels, pools, safety applications, on stairs or emergency exits, traffic signs.

Summary:

All aforementioned facts help improve scientific researches in the field of architecture philosophy in a direct way in order to achieve more coherent and practical results so as to regulate and normalize society contemporary life.

Key words: concept, ecological friendly energy, consume, glow in dark 